\title{
SSynthesis
}

International Scientific Conference of IT and Business-Related Research

\section{ULOGA LJUDSKOG KAPITALA U POVEĆANJU KONKURENTNOSTI PRIVREDE SRBIJE}

\author{
OF THE SERBIAN ECONOMY \\ Vladimir Mitrović, Ivana Mitrović \\ Ekonomski fakultet u Kos.Mitrovici, Srbija
}

THE ROLE OF HUMAN CAPITAL IN INCREASING COMPETITIVENESS

\begin{abstract}
Apstrakt:
Posebnu ulogu u povećanju konkurentnosti i ekonomskog rasta ima ljudski kapital. Zaposleni sa svojim znanjem, sposobnostima i inovativnošću, u velikoj meri doprinose povećanoj produktivnosti, i utiču na poboljšanje konkurentnosti i ekonomski rast. Metodologija ovog rada zasniva se na ljudskom kapitalu i njegovom sveukupnom uticaju, kroz ulaganja u ljude i neophodne veštine, kao jedini način da se očuva i unapredi konkurentska prednost.Potreba za kontinuiranim obrazovanjem uzrokovana je velikim dinamizmom savremenog društva, brzim tehničko-tehnološkim razvojem, posebno u domenu informaciono-komunikacionih tehnologija, što zahteva nova znanja i veštine, kao i nova zanimanja. Prikazani su i indikatori ljudskog kapitala u globalnom indeksu konkurentnosti nacionalne privrede. Poseban naglasak stavlja se na konkurentnost kao jedan od strateških ciljeva razvoja ljudskog kapitala u Srbiji, a naročito politiku koju država može da primeni u ovoj oblasti u cilju jačanja obrazovnog sistema i podizanja nivoa znanja i stručnosti, kao jedan od važnih stubova za podizanje nivoa konkurentnosti, a samim tim i ekonomskog rasta.
\end{abstract}

\section{Ključne reči:}

ljudski kapital, konkurentnost, obrazovanje, znanje, inovacije.

\section{UVOD}

Poboljšanje konkurentnosti država je najveći izazov savremenog društva. Globalna ekonomska kriza uticala je ne samo na zemlje u kojima je nastala (SAD), već su negativne posledice prisutne i u zemljama koje se nalaze na nedovršenom tranzicionom putu, poput naše. Konkurentnost je u takvim uslovima postala ne samo cilj, već i oružje za borbu i izlazak iz krize. U skladu sa tim shvatanjem, posebna pažnja se mora posvetiti konkurentskim pozicijma srpske privrede, koje poslednjih godina ne ostvaruju povoljne rezultate i značajne pomake.

Prema pokazateljima Globalnog izveštaja konkurentnosti (GCR), rang Srbije u 2014.godini nije se bitno poboljšao u odnosu na prethodnu godinu (94. mesto od ukupno 144 rangirane zemlje u odnosu na 101. mesto u 2013. godini). Prema modelu Porterovog dijamanta, poslovno okruženje Srbije ima brojne nedostatke: loša fizička i logistička infrastruktura, velika i prespora državna administracija, masovni odliv stručnjaka i naučnika, pojava tržišne dominacije, loša efikasnost antimonopolske politike, loša regulacija svojinskih prava, nedostatak ulaganja u istraživanje i razvoj, sporo prihvatanje novih tehnologija, nedostupni i nekvalitetni dobavljači, loše stanje razvoja klastera, nedostupnost istraživačkih usluga i obuke. Upravo oblasti koje treba da predstavljaju prioritete za celu državu.

\section{Abstract:}

Human capital plays the crucial role in increasing the level of competitiveness and the overall economic growth. Employees with their knowledge, skills and inventiveness, contribute considerably to increasing productivity, competitiveness and the economic growth. Methodological work is based on the human capital and its impact, by investing in people and development of necessary skills, as the only way to preserve and improve competitive advantage. The necessity for continuous education is triggered by great dynamism of modern society, rapid development of technology, especially information and communication technologies, which requires the development of new knowledge and skills, as well as new professions. This paper presents the indicators of human capital in the global index of competitiveness of the national economy. Special emphasis is placed on competitiveness as a strategic objective of human capital development in Serbia, especially the policy that the state can implement in this area in order to strengthen the education system and enhance the level of knowledge and skills, as one of the important pillars of enhancing the level of competitiveness, which further leads to the economic growth.

\section{Key words:}

human capital, competitiveness, education, knowledge, innovation.

Razvoj se posmatra kao višeslojan proces koji uključuje krupne promene društvenih struktura, stavova ljudi i institucija države (Todaro \& Smith, 2006). Na ovaj način se stvaraju preduslovi za stvaranje modernog ekonomskog modela, pravedne socijalne politike, smanjenje siromaštva, univerzalnog obrazovanja, povećanja kvaliteta života, modernih institucija, demokratije i vrednosti kod pojedinaca i društva u celini. Pri tome, životni standard nekog društva zavisi od njegove sposobnosti da proizvede dobra i usluge, a njegova produktivnost zavisi od fizičkog kapitala, ljudskog kapitala, prirodnih resursa i tehnološkog znanja (Mankiw \& Teylor, 2008). Činjenica je da je prosečan prihod u najbogatijim zemljama sveta deset puta veći nego u najsiromašnijim zemljama. Svakome ko putuje očigledne su velike razlike u prihodu koje dovode do velikih razlika u kvalitetu života. Manje su očigledni razlozi za ove razlike. Istovremeno se otvara pitanje kako bogate zemlje mogu da održe svoj visoki standard življenja, a šta nedovoljno razvijene zemlje mogu da učine kako bi se priključile tom klubu.

Unapređenje konkurentnosti i efikasnosti privrede, zahteva jasno opredeljenje uloge i sagledavanje izazova ekonomije posebno u ovom trenutku. Tu spada: porast produktivnosti (firmi); porast izvoza proizvoda visoke vrednosti; privlačenje stranih investicija; korišćenje moderne tehnologije i inovacija; investiranje u ljudski kapital; unapređenje osposobljenosti obra- 
zovanjem; stvaranje klastera u visoko prioritetnim sektorima. Tehnološki nivo razvoja u kombinaciji sa ljudskim kapitalom ima esencijalni značaj za nivo produktivnosti. Bez obzira što ljudski kapital nije precizno definisan, ljudi, njihovo znanje i veštine kao i obrazovanje, istraživanje i inovativnost u velikopj meri utiču na povećanje produktivnosti, poboljšanje konkurentnosti i ekonomski rast. Pošto ljudski kapital predstavlja ozbiljnu ekonomsku snagu, ciljj je da ljudi budu obrazovani, ali ne i da njihov rad bude jeftin. Laureat Nobelove nagrade Gary S. Becker (1975) navodi da samo ulaganja za obrazovanje, obuku, medicinsku negu proizvode ljudski, a ne fizički ili finansijski kapital, jer se ne mogu odvojiti osobe od njihovih znanja, veština, zdravlja ili vrednosnog sistema. Veći ljudski kapital poboljšava rast, jer se na taj način zemlja priključuje najnaprednoj tehnologiji. Naravno, ljudski kapital ne samo da prihvata napredne tehnologije, već inovativnošću stvara nove tehnologije. Valja imati na umu da ljudski kapital poseduju ljudi, a ne kompanije i da su ljudski i fizički kapital inputi u proizvodnji i njihov udeo u nacionalnom prihodu je skoro jednak. Weil (2009), ističe da su akumulacija ljudskog kapitala i uticaj ljudskog kapitala na proizvodnju analogni sa akumulacijom i uticajem fizičkog kapitala. Razlike u akumulaciji ljudskog kapitala među zemaljama, daju objašnjenje zašto su neke zemlje bogate, a druge siromašne kao što je slučaj sa akumulacijom fizičkog kapitala. Takođe, investicije u obrazovanje koje stvaraju ljudski kapital su slične investicijama koje proizvode fizički kapital.

Postoji saglasnost većine ekonomista da su znanje i inovacije osnova privrednog i sveukupnog razvoja i da su izuzetno nadareni ljudi, naučnici i kadrovski profili tehničkih struka nosioci inovativnih promena. Zato je i tražnja za talentovanim i nadarenim ljudima i inovatorima sve veća u svetu. Kada je reč o Srbiji po kvalitetu ljudskog kapitala koga determinišu, formalno i neformalno obrazovanje na svim nivoima, a naročito na visokoobrazovnom nivou, ono je relativno skromnih razmera. Iako je obavezno osmogodišnje osnovno obrazovanje za sve stanovnike u Srbiji, već više od pola veka, statistički podaci pokazuju da preko milion lica u Srbiji nije završilo osnovnu školu i čak milion i po stanovnika ima samo diplomu osnovne škole. Nezadovoljavajući nivo zavrašenog osnovnog obrazovanja počinje time što ne upisuju sva deca osnovnu školu, uočen je trend smanjenja upisa dece na selu, za oko $2 \%$ u periodu 2005 2008. godine. Problem narasta osipanjem dece iz osnovnih škola. Veliki problem je osipanje dece iz osetljivih grupa, pre svega seoske i romske dece. Godine 2005. u peti razred je prelazilo oko $95 \%$ dece u gradskim i $92 \%$ dece u seoskim sredinama, a 2008. godine osipanje seoske dece bilo je $14,25 \%$, a $50 \%$ romske dece. Po podacima iz 2010. godine romska deca iz segregisanih naselja njih $78 \%$ se upisuje u osnovno obrazovanje, a završava ga $34 \%$. Po evropskim dokumentima osipanje dece u toku osnovnog obrazovanja trebalo bi da bude ispod 10\% (Strategija razvoja obrazovanja u Srbiji do 2020. godine). Tu je i nezaobilazni podatak da je više od 70\% nepismenih građana starije od 65 godina. Statistički podaci takođe, pokazuju da se Srbija sa svojih $6,5 \%$ fakultetski obrazovanih građana nalazi na dnu lestvice zemalja Evrope. Podaci OECD-a pokazuju da je prosečan procenat fakultetski obrazovnih ljudi u EU 2007. godine bio oko $25 \%$, a smatra se da normalno razvijena zemlja treba da ima najmanje $20 \%$ visokoobrazovnih ${ }^{1}$. Na priču o ljudskom kapitalu Srbije se nadovezuje i odliv talenata i stručnih kadrova. Čak, mnogo više brine trend da se odliv talenata Srbije povećava iz godine u godinu, pa je sadašnje pretposlednje mesto u globalnom indeksu konkurentnosti nacionalne privrede njegova

1 Prema novoj strategiji EU do 2020. godine jedan od ciljeva je povećanje udela stanovnika sa završenim visokim (tercijalnim) obrazovanjem sa sadašnjih $31 \%$ na najmanje $40 \%$, u populaciji starosti između 30 i 34 godine do 2020 . godine. kulminacija. Loš plasman ukazuje na činjenicu da školovani kadar u Srbiji ne može da dođe do poslova koji će biti adekvatno plaćeni ili da dođe do posla uopšte, pa šansu da naplati svoje obrazovanje traži u nekoj drugoj zemlji. Naši talenti i kvalitetni kadrovi u uslovima sve veće tražnje, nalaze mesto u državama koje im pružaju najbolje uslove za ispoljavanje kreativnosti koju poseduju. Odnosno, države koje pružaju odgovarajuću infrastrukturu i druge uslove koji omogućavaju ostvarivanje najboljih rezultata u njihovom stvaralaštvu. Jednostavno, oni u zemlji prijema imaju veće plate, bolje uslove rada, bolje zdravstveno i socijalno osiguranje nego što je naša zemlja najćešće u stanju da im pruži. Nažalost Srbiju je tokom poslednjih decenija, napustio veliki broj talenata, naučnih radnika i istraživača. Prema procenama koje su preneli srpski mediji u inostranstvu danas radi više od 5.000 doktora nauka i preko 30.000 stručnjaka. I tu nije kraj, jer se za dogledno vreme očekuje nastavak, u većoj ili manjoj meri, emigracije kvalitetne radne populacije iz Srbije, dok se uopšte ne može računati na značajnu imigraciju ovakve populacije ka Srbiji.

Savremene tendencije razvoja zemalja tržišne privrede pokazale su da se obrazovanje i stvaranje ljudskih resursa, kada je reč o razvoju i primeni novih tehnologija, nalaze u samom vrhu prioriteta globalnih nacionalnih strategija i politika socijalnog, ekonomskog i tehnološkog napretka. Imajući u vidu da se efekti obrazovanja ne odražavaju samo na pojedince, nego i na društvo u celini, može se reći da znanje postaje osnovni razvojni faktor i da se politika obrazovanja ne tretira samo kao politika kreiranja ljudskog kapitala, već i kao deo razvojne politike. Pravilno upravljanje ljudskim resursima je direktan izvor poboljšanja kvaliteta, produktivnosti, pa sa tim i konkurennosti, što podrazumeva kontinuirano razvijanje i usavršavanje tih resursa. Za Srbiju je neophodno ulaganje u srednje i visoko obrazovanje. Nivo tehnološkog razvoja Srbije je takav da omogućava kopiranje tehnologija. Kopiranje tehnologije podrazumeva umeće korišćenja postojećih tehnologija i umeće izarde proizvoda sa dostignutim nivoom tehnologije (proizvodna imitacija). Istovremeno, pažnja se mora usmeriti na komparativne prednosti koje Srbija poseduje u smislu razvoja turističkih usluga koje omogućavaju reke, planine, banje, kuturna dobra i sl. U tom smislu, u oblasti poljoprivrednih proizvoda neophodno je povećanje produktivnosti uz kvalitativni pomak u standardima koje zahteva tržište.

\section{KRETANJE INDIKATORA LJUDSKOG KAPITALA U GLOBALNOM INDEKSU KONKURENTNOSTI NACIONALNE PRIVREDE}

Kao jedan od najvažnijih indikatora o stanju ljudskog kapitala u jednoj zemlji izdvaja se ulaganje u obrazovanje i obrazovni sistem. Investiranje u ljude i veštine je neophodno, jer je to jedini način da se očuva i unapredi konkurentska prednost. Potreba za stalnim obrazovanjem je uzrokovana velikim dinamizmom savremenog društva, brzim tehničko-tehnološkim razvojem, posebno informaciono-komunikacione tehnologije (u daljem tekstu IKT) što zahteva stvaranje novih znanja i veština, kao i stvaranje novih zanimanja. U tom smislu, razvijene zemlje i zemlje u razvoju nastoje da podignu nivo sopstvene spremnosti za razvoj ekonomije znanja. Međutim, kad je reč o Srbiji poseban problem u nastojanjima da se unapredi sistem obrazovanja je činjenica da se ona nalazi u procesu tranzicije, i da je značajno pogođena velikom ekonomskom krizom, što stvara problem finansiranja i funkcionisanja sistema obrazovanja. Pozicija Srbije u svetu prema indikatorima visokog obrazovanja i obučavanja, u poslednje četiri godine nije zadovoljavajuća. Prema stepenu upisa na fakultete Srbija je pogoršala svoj položaj, sa 49. mesta 
2010-2011. godine na 52. mesto u 2014-2015. godini. Zabrinjavajuće je pogoršanje pozicije Srbije prema kvalitetu obrazovnog sistema. Iz Svetskog ekonomskog foruma posebnu pažnju poklanjaju kvalitetu obrazovanja u oblasti nauke i matematike, a naša pozicija se pogoršala, u četvorogodišnjem periodu, za sedam mesta, sa 48. na 53. mesto. Kada se radi o kvalitetu škola za menadžment, pozicija Srbije se pogoršala za trinaest mesta, 2014. godine među 144 zemlje Srbija je zauzela 114. mesto. Od svih indikatora koji se odnose na visoko obrazovanje i obučavanje, najnepovoljnija je pozicija u pogledu postojanja odgovarajućih kadrova za obuku, 134. mesto od ukupno 144 zemlje (World Economic Forum, 2015).

Kada je reč o efikasnosti tržišta rada u Srbiji , analize Svetskog ekonomskog foruma pokazuju da ta efikasnost našoj zemlji nije jača strana. Prema saradnji između poslodavaca i sindikata, Srbija se u 2014. godini nalazila na 140.mestu od ukupno 144 zemlje, posle Albanije (37. mesto), Makedonije (63. mesto), Crne Gore (106. mesto) i Hrvatske (126. mesto). Međutim, ono što najviše zabrinjava jeste efikasnost „korišćenja“ talenata. Ta efikasnost je sagledana preko četiri pokazatelja: odnos zarada i produktivnosti, neprihvatanje profesionalnog menadžmenta, sposobnost zemlje da privuče talente. Podaci pokazuju da Srbija pati od hronične nesposobnosti da privuče talente, budući da se nalazi na 143. mestu, od ukupno 144 zemlje, da je profesionalni menadžment zapostavljen i da država ne brine o svojim talentima. Prema odrednici „sposobnost zemlje da privuče talente“, Srbija se nalazi iza Albanije (98. mesto). Crne Gore (97. mesto), Makedonije (134. mesto), Hrvatske (141. mesto) (World Economic Forum, 2015).

Vrlo važan momenat za konkurentnost privrede jesu tehnološke inovacije. One su osnovni faktor unapređenja konkurentnosti preduzeća, čiji se značaj posebno povećava u savremenoj privredi, koju karakteriše koncept razvoja zasnovan na znanju. Kod zemalja inovatora i lidera u tehnološkim promenama, u skladu sa zahtevima konkurentnosti realnih privreda, komponenta tehnologije dobija veliki ponder (50\%). Svetski ekonomski forum je značaj inovacija za konkurentnost nacionalne privrede obradio na bazi sedam pokazatelja. Tako se po kapacitetu za inovacije, Srbija nalazi na 136. mestu. Kad se upoređuje sa stanjem u 2010-2011. godini, vidi se da je zabeležen značajan pad, budući da je pozicija na rang listi pogoršana (54. mesto). Prema rezultatima Inovation Union Scoreboard (2011) Sbija pripada trećoj grupi zemalja koje predstavljaju umerene inovatore, sa inovacionim performansama koje su ispod proseka. Prema objavljenim podacima RZS posmatrano prema veličini preduzeća, mala preduzeća čine najveći broj preduzeća-inovatora, slede srednja preduzeća, dok velika preduzeća učestvuju sa $14 \%$. Najveći intezitet inovacija postignut je u organizaciji preduzeća (32,5\%), a najmanji u inovacijama proizvoda/usluga $(27,4 \%)$, dok su inovacije u proces proizvodnje i u marketing zastupljene sa 29,3\% (RZS, 2011).

Kvalitet naučno-istraživačkih institucija je, bez sumnje, vrlo značajan činilac naučno-tehnološkog razvoja. Nažalost, ankete pokazuju da se u zadnje tri godine pozicija Srbije pogoršava, sa 56. mesta 2010-2011. godine, na 136. mesto 2014-2015. godine. To je, između ostalog, posledica niske stope izdvajanja sredstava za istraživanje i razvoj. Srbija izdvaja vrlo malo sredstava iz budžeta za istraživanje i razvoj, manje od $0,4 \%$ bruto domaćeg proizvoda. Pritom su rashodi preduzeća za istraživanje i razvoj gotovo zanemarujući. Po toj odrednici Srbija se 2014-2015. godine našla na 125. mestu. Saradnja između naučno-istraživačkih organizacija i privrednih subjekata pokazuje određene uspone i padove. Ono što pokazuje pogoršanje pozicije Srbije jeste u segmentu raspoloživosti naučnika i inžinjera i primeni patenata (World Economic Forum, 2011; World Economic Fo- rum, 2015). To je posledica emigracije naučnika i inžinjera iz Srbije. Ukoliko se u računicu uključi srpska naučna dijaspora iz svih delova sveta, onda se prema procenama može govoriti o potencijalu od preko deset hiljada, koji u tom slučaju premašuje razmere današnje naučne zajednice. Inače, kad smo kod pitanja povećanja tehnološke konkurentnosti najveća ulaganja $\mathrm{u}$ istraživanje i razvoj tokom XX veka imale su visokorazvijene zemlje. U ovim zemljama se, u istom periodu nalazi preko $90 \%$ istraživačko-razvojnih kapaciteta i one su potrošile više od $3 / 4$ ukupnih svetskih izdataka na R\&D (Kozomara, 1994 ). Empirijski podaci pokazuju direktnu vezu između visokog udela troškova za R\&D u društvenom proizvodu i visokog udela zemlje u svetskom izvozu, odnosno visok stepen konkurentnosi izvoznih proizvoda te zemlje.

Kvalitet studenata, radnika, menadžera i istraživača određuje inovacioni kapacitet zemlje i osnova je za ekonomsku konkurentnost i prosperitet. Nobelovac Jozef Stiglic ističe da se mnogi ekonomisti i kreatori ekonomskih politika slažu da bi unapređenje ljudskih resursa (kvalifikacija i veština) predstavljalo ključ za povećanje produktivnosti, a najvažniji preduslov za ostvarenje tog cilja jeste kvalitetno obrazovanje (Stiglic, 2004). Razvijene privrede i zemlje u razvoju se fokusiraju na inovaciju, nadmeću se globalno za talenat, resurse i tržišne udele. Uspešne zemlje XXI veka su one čiji su građani kreativni, prilagodljivi i obučeni. Zbog toga se danas govori o ekonomiji zasnovanoj na znanju. Koliki je značaj obrazovanja i znanja vidi se iz činjenice da se razvoj zasnovan na znanju i inovacijama nalazi u osnovi „pametnog rasta“, jednog od tri stuba strategije razvoja EU. Pametan rast se zasniva na poboljšanju kvaliteta obrazovanja, jačanju istraživačkih kapaciteta, promociji inovacija, transferu znanja, punoj primeni informaciono-komunikacionih tehnologija (u daljem tekstu IKT) i omogućavanju da inovativne ideje budu primenjene na nove proizvode i usluge u cilju stvaranja uslova za novi rast, kvalitetnije zapošljavanja i povećanje konkurentnosti. S obzirom da su visokoobazovni kadrovi odlično plaćeni, odnosno kako je industrija znanja sama po sebi profitabilna, iz nje proističu i veliki porezi za državu. Na taj način i sama zemlja finansijski jača što omogućava veće izvajanje sredstava za razvoj nauke i obrazovanja i stvaranje novih kreativnih i inovativnih kadrova.

Efikasna tržišna privreda usmerena je na porast blagostanja svih građana i moguća je samo u uslovima pune demokratizacije društva koja se zasniva na snažnim državnim i društvenim institucijama i valdavini prava. Srpska privreda se opredelila za kontinuirano podizanje svoje konkurentnosti, jer je to bitna predpostavka ostvarivanja razvojnih ciljeva i punog korišćenja prednosti koje nam nudi članstvo u EU. Međutim, brojne analize pokazuju da razlozi niske konkurentnosti leže u najvećoj meri u nama samima, često se čekaju spoljna rešenja i pomoć, a država se nedovoljno angažuje u nalaženju efikasnih rešenja unutar domaće privrede. Nema sumnje, mnogo toga je moglo i još uvek može da se ostvari bez stranih ulaganja i inostranih tehnoloških rešenja. Radi se, pre svega o kompletiranju i poboljšanju javnih i privatnih institucija, poštovanju zakona, smanjenju protekcionizma davanju šanse svima. S obzirom da je konkurencija glavna poluga tržišne privrede to je zadatak države da u interesu građana izgradi efikasanije institucije tržišne privrede i odlučno se suprostavi svim oblicima monopolskog i drugog privilegovanog položaja, što podrazummeva i uvođenje tržišnih kriterijuma i javno-privatnog partnerstva u infrastrukturne delatnosti koje su kičma moderne privrede. Na taj način bi se stvorili bolji uslovi i manji odliv talenata iz zemlje i podstaklo bi se profesionalno upravljanje na svim nivoima.

Nova vrednost se stvara poboljšanjem protoka znanja unutar organizacije i pretvaranje tog znanja u vrednost. Kako je već spomenuto Srbija glavnu dugoročnu konkurentsku prednost 
ima u znanju koje može da iskoristi, kroz reformu obrazovanja, većim naglaskom na istraživanje i primenu inovacija, kao i bržim razvojem IKT. Razvoj računarske tehnologije, polako ali sigurnim korakom vodi do toga da IKT postaju osnova ekonomije i tržišta kakve danas poznjemo. Čime se potvrđuje da u današnje vreme velike kompanije i moderni poslovni sistemi mogu poslovati, ako se promeni vlasnička struktura kapitala, ali isto tako njihovo funkcionisanje i razvoj teško je zamisliti ako se ne primenjuje savremena IKT. Ova promena u osnovnim principima organizacije vrlo jasno pokazuje da je poslovanje prešlo iz klasičnog industrijskog kapitalizma u ekonomiju znanja. IKT omogućava pojedincima preduzećima i društvenim organizacijama, da se suoče sa ekonomskim i socijalnim izazovima sa većom efikasnošću i maštom. Na ovaj način, IKT doprinosi stvaranju društva znanja baziranog na delenju (pristupu) informacijama i uključivanju svih socijalno kulturnih i etičkih dimenzija u održivi razvoj i veću koheziju društva. Naravno, ako je prisutna razmena znanja i informacija na svim nivoima, onda je to način da se čuvaju resursi, razvijaju novi proizvodi i usluge, stvaraju nove mogućnosti i u krajnjoj instanci, opstane na tržištu. Koristeći IKT, kompanije (preduzeća) mogu mnogo preciznije da izmere svoje aktivnosti i da motivišu zaposlene da uspešno sprovode strategije. Pri tome veza između IKT i povećanje produktivnosti sve više postaje dvoznačna i povezana sa putanjom učenja. Naravno, nove tehnologije doprinose poboljšanju performansi samo posle perioda adaptacije ljudi i organizacija.

Iz ugla konkurentnosti kompanija (preduzeća), na nivou zemlje potrebno je stvoriti i međunarodno kompetentan sistem visokog i doživotnog obrazovanja u kome je izvršena efikasna sinteza njegova tri osnovna oblika: formalnog, neformalnog i informalnog obrazovanja. Sve u funkciji: obrazovanja stručnjaka potrebnih za iniciranje i realizaciju složenih razvojnih projekata, obrazovanja lidera i menadžera, sa jedne strane, i pripreme novih radnika za uvođenje u posao, obrazovanja zaposlenih koji ne ostvaruju odgovarujuću produktivnost i kvalitet rada i obrazovanja u funkciji napredovanja i razvoja individualnih planova karijere, sa druge strane. U tom smislu, Ministarstvo prosvete, radi unapređenja kvaliteta visokog obrazovanja, zajedno sa resornim Nacionalnim savetom, s pravom ulaže napore u pravcu podizanja standarda u visokom obrazovanju-uključujući i standarde naučne kompetentnosti nastavnika, kao i istraživača. Takođe, Ministarstvo za nauku i tehnološki razvoj ulaže napore u pravcu podizanja indeksa citiranosti naših istraživača i nastavnika. Posebna pažnja se posvećuje procesu akreditacije visokoškolskih ustanova i potrebi da nastavnici ispune postavljene standarde, ako žele da zadrže zvanje ili da napreduju. Ovo su naravno samo delovi koje značajne reforme obrazovnog sistema treba da imaju u svom programu. Istovremeno, to za pojedince znači i obavezu stalnog učenja i razvoja, praćenja promena u znanju i praćenje potreba tržišta rada.

\section{KONKURENTNOST KAO CILJ STRATEGIJE RAZVOJA LJUDSKOG KAPITALA U SRBIJI}

Postoji opšta saglasnost da je raspolaganje ljudskim kapitalom najvišeg kvaliteta krucijalni činilac u efektivnom upravljanju održivim razvojem i u strategiji razvoja najvećeg broja zemalja u svetu. Pri tome, upravljanje ljudskim resursima nameće potrebu iznalaženja odgovarajućih modelskih pristupa i institucionalne podrške, koji će obezbediti, pre svega, povoljnu klimu u zemlji i instrumente za ostvarivanje fundamentalnog cilja „smanjenja odliva talenata“ i omogućiti znatniji „priliv znanja“ radi izgradnje konkurentske prednosti privrednih subjekata u zemlji. U ovom smislu, pored cilja, neophodno je postojanje jasne vizije, motivisanosti i posvećenosti članova tima, kreativnost, vertikalna i horizontalna saradnja sa drugim učesnicima, kao i jasna i iskrena komunikacija, koordinacija i kontrola nadležnog državnog organa. Kako je funkcija cilja ostvarivanje konkurentske prednosti nacionalnih razvojnih subjekata to znači da se upravljanje ljudskim resursima odnosi na politiku, praksu i strukturu, koje utiču na ponašanje poslovnih subjekata i na njihove stavove i radnu uspešnost. Otuda se konkurentnost odnosi na sposobnost državnih i privrednih subjekata da zadrže i povećaju tržišni udeo unutar svog delovanja.Takođe, konkurentnost se odnosi i na široki spektar relacija i odnosa, koje se kroz dinamiku razvoja mogu stalno nadograđivati i usavršavati.

U stručnoj javnosti često čujemo protivurečne stavove po pitanjima znanja i obrazovanja u Srbiji. Neki od uzroka nezaposlenosti u Srbiji su: nedovoljan priliv direktnih stranih investicija, slaba ponuda poslova, veliki broj osoba sa niskim kvalifikacijama, ali i neodgovarajući sistem obrazovanja, koji praktično proizvodi kadrove koji po sticanju diplome završavaju kao nezaposleni na tržištu rada. Tačna je činjenica o nedovoljnoj usklađenosti obrazovanja i tržišta rada, posebno kada je reč o praktičnim znanjima i veštinama. Sve više je prisutan problem da ljudi sa završenom školom ne poseduju odgovarajući stepen veština, sposobnost za samostalno rešavanje problema, analitičku sposobnost, sposobnost za timski rad na projektima. Svedoci smo i da razvoj ekonomije pooštrava zahteve u pogledu kvalifikacija za ulazak na tržište rada i da se u narednom periodu može očekivati da minimum za ulazak na tržište rada bude završeno srednje obrazovanje.U ovom smislu, suština promena u srednjem stručnom obrazovanju treba da bude nastojanje da se uspostavi fleksibilan sistem stručnog obrazovanja koji bi odgovorio na izmenjene zahteve tržišta rada i omogućio sticanje znanja i vrednosti za kvalitetniji i brži profesionalni razvoj i karijeru.Visoko kvalitetno obrazovanje treba da stvara takve stručnjake koji će moći da se uključe u oštru međunarodnu konkurenciju.Univerzitet treba posmatrati kao mesto sticanja znanja, obavljanja profesionalne delatnosti i mesto koje kreira kulturni i društveni razvoj.Važno je razvijati i partnerstvo univerziteta sa privredom i međunarodnim institucijama.

Kada je u pitanju korišćenje znanja sudeći po dosadašnjim iskustvima čini se da državni organ Srbije, odnosno, oni koji su zaduženi za saradnju sa dijasporom, ne koriste raspoloživo znanje koje posedujemo u zemlji, u meri u kojoj je to moguće i potrebno. Dakle, nije važno imati samo kapacitet i resurse da bi iz krize izašli kao pobednici. Potrebno je preduzeti akcije, što zahteva sposobnost, volju i interes da se okupe i aktiviraju svi ljudski potencijali iz zemlje i inostranstva, kako bi zajedno tražili optimalna rešenja za sve probleme sa kojima se Srbija suočava. Kako je objasnila Dr Ljubica M. Zjalić (2011) „Znanje kao strukturisana moć uma, koje menja ljude i prilike, preuzimajući odgovornost za kvalitet ljudskih resursa, moglo bi da dovede do zaokreta ka porastu zaposlenosti, pa i privrednom rastu“. Ako smo ušli u novo doba-doba znanja, onda je očigledno da će osnova našeg delovanja, od danas pa nadalje, biti racionalnije korišćenje tog najvrednijeg resursa. Naime, postoji opšta saglasnost da visokostručna lica čine najveći i najznačajniji potencijal i razvojni resurs. Zato je potrebno zajedničko i usklađeno delovanje odgovarajućih ministarstava, socijalnih partnera, obrazovnih ustanova i tržišta rada. Naravno, infrastruktura obrazovanja/učenja podrazumeva i pravnu regulativu, uređena prava i obaveze finansiranja od strane državnih, regionalnih i lokalnih struktura i fondova, izgrađenu mrežu ustanova, udruženja i fondacija koje realizuju programe u ovoj oblasti.

Činjenica je da su odnosi između stručnjaka u dijaspori i onih u zemlji matici često postojali i u prošlosti, ali strateški pristup novijeg datuma treba da bude takav da se ove spora- 
dične, vanredne i ograničene veze učine sistemskim čestim i raznovrsnim. U tom smislu, Vlada treba da podstiče i pomaže samoorganizovanje srpske intelektualne dijaspore i njihove mreže. Intelektualne mreže u dijaspori treba da predstavljaju most između stručnog i naučnog potencijala u zemljama destinacije i stručnog i naučnog potencijala u zemlji matici. Razume se, ciljevi razvoja nameću potrebu i da država bude otvorena za zapošljavanje najboljih stručnjaka/talenata iz inostranstva bilo da su pripadnici naučne dijaspore ili ne. Kada je u pitanju intelektualna dijaspora važne su i odgovarajuće institucije civilnog sektora koje bi promovisale politiku povratka stručnjaka, kao i politiku saradnje na daljinu sa srpskom naučnom dijasporom. Očito je da država Srbija kao institucija nije u mogućnosti da realizuje takvu akciju bez šire podrške društva.

S druge strane, neophodno je kontinuirano stvaranje povoljnog i atraktivnijeg ekonomskog i društvenog okruženja. Potrebno je zaustaviti gubitak velikog intelektualnog potencijala stvaranjem uslova za realizaciju profesionalnih opredelenja u zemlji. Posebno je važno i da se u narednom periodu uspostavi efikasnija i bilateralna saradnja sa zemljama EU i drugim razvijenim ekonomijama, naučnim i specijalizovanim institucijama u svetu na naučno-tehničkom, kulturnom i drugom planu, a radi obezbeđivanja odgovarajuće specijalizacije, stručnog usavršavanja mladih intelektualaca iz Srbije uz obezbeđivanje njihovog povratka i profesionalnog angažovnja u zemlji matici. Tržište rada za istraživače i inovatore, kako u pogledu zakonskih rešenja tako i u pogledu funkcionisanja, treba i kod nas, kako to čine sve evropske zemlje, da je harmonizovano sa rešenjima EU. Kreatori politike u našoj zemlji treba da obezbede uslove kojima će osigurati da karijera istraživača bude što privlačnija i da se smanje i progresivno eliminišu prepreke koje još uvek onemogućavaju mobilnost istraživača.

Istaknut je značaj ulaganja u ljudski kapital. Međutim, nivo ulaganja u obrazovanje u Srbiji je veoma nisko. Ministarstvo nije uspelo da učini značajniji korak u pogledu izdvajanja sredstava za istraživanje i razvoj. Tako se Srbija prema izdvajanjima za istraživanje i razvoj nalazi na samom dnu liste zemalja. U prvoj deceniji novog veka Srbija je izdvajala za istraživanje i razvoj $0,1 \%$ do $0,41 \%$ bruto domaćeg proizvoda. Privreda Srbije nije izdvojila značajna sredstva i o tome nema preciznih podataka. Procenjuje se da ukupna ulaganja u nauku u Srbiji ne prelaze 0,5\% BDP-a, što Srbiju još uvek svrstava među zemlje sa najmanjim ulaganjima u nauku, kako u razvijenom svetu, tako i u regionu. Osim niskog izdvajanja za nauku brine i odsustvo jasnog pozitivnog opredeljenja o povećanom izdvajanju. Investiranje u ljude i veštine je neophodno, jer je to jedini način da se očuva i unapredi konkurentska prednost. Osim što je bitno koliko se izdvaja za obrazovanje, bitno je i kako se raspoređuje ulaganje u obrazovanje i da li je ta raspodela u interakciji sa okruženjem i tražnjom okoline (nije svejedno gde će koji fakultet ili institut biti raspoređen).

Specifične preduzetničke, menadžerske i veštine ostalih zaposlenih su ključni resurs u kreiranju sposobnosti preduzeća za ekspanziju na nova proizvodna i geografska tržišta. To podrazumeva da preduzeće zapošljava veliki broj visookokvalifikovanih pojedinaca koji poseduju i veštine: informatičku pismenost, poznavanje stranih jezika, organizacijske veštine, mobilnost i sposobnost učenja i savladavanja novih tehnologija, jer samo postojanje takvih sposobnosti menadžera i zaposlenih u preduzeću omogućavaju konkurentsku prednost na tržištu. Kako je već pomenuto, pravilno upravljanje ljudskim resursima je direktan izvor poboljšanja kvaliteta i produktivnosti, pa samim tim i konkurentnosti, ali istovremeno taj resurs se mora kontinuirano razvijati i usavršavati. $U$ tom smislu, značajno mesto u svakom preduzeću moraju zauzeti profesionalni treninzi, konsultantska podrška, stručno obrazovanje i razvoj posebnih veština menadžera i zaposlenih.

U društvima koja se zasnivaju na znanju, obrazovanje odraslih i doživotno obrazovanje postali su neophodnost u cilju održavanja i povećanja konkurentnosti zaposlenih. Novi zahtevi koje postavlja društvo i radna sredina očekuju od svakog pojedinca da nastavi sa obnavljanjem, inoviranjem znanja i veština tokom celog života. Novi koncept obrazovanja predstavlja izazov postojećim praksama, jer je za njega potreban efikasan sistem unurtar formalnih i neformalnih obrazovnih sistema, modernizacija i veća kreativnost i fleksibilnost. To zahteva novi pristup obrazovanju odraslih unutar koncepta doživotnog učenja. Prema definiciji Evropske komisije, doživotno učenje je učenje koje se preduzima tokom celog života, s ciljem poboljšanja znanja, veština i kompentencija u okviru lične, građanske, društvene perspektive ili vezano za zaposlenje. Ono podstiče socijalnu uključenost pojedinca i razvija njegove sposobnosti što vodi do ličnog zadovoljstva. Krajnji cilj podsticaja doživotnog učenja je stvaranje društva koje uči i koje teži socijalnom i opštem dobru, razvijanje kvalifikacija temeljenih na kompetencijama i rezultatima učenja, trajno usklađivanje obrazovanja s potrebama tržišta rada, izgradnja sistema obrazovanja i osposobljavanja koji omogućava doživotno učenje i mobilnost. Upravo u tom segmentu neformalno obrazovanje dobija na značaju, jer treba da obezbedi sprovođenje principa doživotnog učenja i kompenzira nedostatke formalnog obrazovanja.

Da bi se poboljšalo obrazovanje odraslih i u potpunosti usvojio koncept doživotnog učenja bitna je saradnja između svih zainteresovanih strana: ministarstva, poslodavca, sindikata, asocijacija privrede i neprivrede, nevladinih organizacija koje zajednički deluju u stvaranju mogućnosti za trajno učenje i osiguravaju priznanja, potvrde i primenljivost. Neophodna su nova partnerstva zainteresovanih strana, posebno među predstavnicima obrazovnih institucija i poslodavaca. Posebna pažnja se mora usmeriti na način priznavanja i vrednovanja kvalifikacije stečene u procesu neformalnog obrazovanja, saradnju i razmenu iskustva između univerziteta, obrazovnih institucija i davalaca edukacije, benčmarking, primenu „tehničkog govora kvalifikacija“, koji se ogleda u primeni standarda i „socijalnog govora kvalifikacija“ odnosno motivacije za učenje u cilju uspostavljanja kvaliteta i vrednosti kvalifikacija na tržištu rada. Takvo delovanje stvara klimu koja razvija „društvo znanja“ i „organizacije koje uče“. Na duži rok se postiže i kultura učenja.

Preduzetnički razvoj je nezaobilazna komponenta za unapređenje konkurentnosti u Srbiji. Teorija i praksa ukazuju na to da preduzetnički način razmišljanja i upravljanja stvaraju mogućnost kreiranja održive konkurentske pozicije. U tom smislu, bitno je ostvariti veću posvećenost preduzetničkom obrazovanju referentnih institucija nadležnih za obrazovanje. U proteklom periodu stvaranje partnerstva za doživotno učenje u oblasti preduzetništva u Srbiji je išlo sporo, mada je svest o značaju saradnje već prisutna kod velikog broja zainteresovanih strana. Do sada je naglasak bio na preduzetništvu u okviru stručnog obrazovanja, a sada je neopohodno posvetiti veću pažnju modalitetima uvođenja preduzetništva na svim nivoima formalnog obrazovanja (osnovnom, srednjem i visokom). Takođe, što se tiče neposredne realizacije obrazovnih programa ističe se da se pitanjem razvoja ključnih preduzetničkih veština treba baviti sistemski. Posebno je neophodno podsticati saradnju između škola i preduzeća. Preduzetnike je potrebno motivisati da se povezuju sa fakultetima i naučno-istraživačkim institucijama u cilju ostvarivanja zajedničkih projekata. Kompanije, instituti i fakulteti mogu zajednički ulagati u razvoj novih proizvoda ili inovirati postojeće. Takođe, treba otvarati centre za zajednička istraživanja. 
Dakle, ako želimo da postanemo član EU, onda treba činiti što i zemlje ove, za nas najvažnije integracione grupacije. Politiku treba dograditi dodatnom funkcijom države u upravljanju znanjem.

\section{REZIME}

Danas, u vremenu globalizacije i sveopštih reformi, kada se favorizuje kapital, pouzdano se može reći da je glavni pokretač privrednog razvoja produktivnost rada, koja se zasniva na znanju, inovacijama, pronicljivosti, tj. na razvoju ljudskog kapitala. S obzirom na to da je naš cilj da izgradimo konkurentsku prednost nacionalnih razvojnih subjekata, upravljačke akcije treba da budu usmerene na politiku, praksu i strukturu, koje zajedno treba da utiču na ponašanje subjekata i na njihove stavove i radnu uspešnost.

Ljudi mogu da postanu produktivniji, ako se obrazuju i povećavaju svoju zaradu, što predstavlja investiranje u ljudski kapital. Savremene tendencije razvoja zemalja tržišne privrede pokazale su da se obrazovanje i stvaranje ljudskog kapitala, kada je reč o razvoju i primeni novih tehnoloških dostignuća, nalaze u samom vrhu ciljnih prioriteta globalnih nacionalnih strategija i politika socijalnog, ekonomskog i tehnološkog napretka. To je razumljivo, jer obrazovanje doprinosi ujednačavanju životnih prilika, razvoju ličnosti u duhu slobode, doprinosi intelektualnom razvoju i duhovnom i kulturnom bogatstvu. Naravno, imajući u vidu da se efekti obrazovanja ne odražavaju samo na pojedince, već i na društvo u celini, može se reći da znanje postaje osnovni razvojni faktor. Kvalitetno obrazovanje stvara stručnjake koji će moći da se uključe u oštru međunarodnu konkurenciju. Napreduju samo oni koji znaju nemilosrdno pravilo, da se jedino najorganizovaniji, najsposobniji i najbolji, tj. samo oni najkvalitetniji reflektuju na prvo mesto.

$\mathrm{Na}$ osnovu prikazanih indikatora, može se zaključiti da nam je potrebna nova perspektiva i novi instrumenti-pristupi konkurentnosti koji su na međunarodnom planu uspešni. Zato je neophodno poboljšanje saradnje kompanija u oblasti industrije sa naučno-istraživačkim institucijama na duži rok i obezbeđenje programa edukacije i treninga. Menadžerske aktivnosti za stvaranje i povećanje vrednosti ali i njeno inoviranje, predstavljaju imperativnu potrebu za očuvanje pozicija organizacija i ostvarenje konkurentske prednosti u globalnim razmerama. Kvalitet poslovnih mreža i prateće industrije, važan je iz različitih razloga. Kada su preduzeća i dobavljači iz pojedinih sektora međusobno povezani, pojačana je delotvornost, stvorene su veće mogućnosti za inovacije, a smanjene su prepreke za ulazak novih preduzeća. Razvoj uspešnog lanca vrednosti značajno može pomoći u tim aktivnostima. Konačno, pojedinačne aktivnosti i strategije kompanija (brending, marketing, jedinstvenost i prefinjenost proizvoda), mogu dovesti do sofisticiranih i modernih procesa.

Činjenica je da obrazovni sistem u Srbiji nije dovoljno brzo reagovao na promene nastale u okruženju. Srbija je zemlja iz koje se regrutovao znatan broj migrirajućih naučnika; samo tokom poslednje dve decenije, Srbiju je napustilo mnogo stručnjaka. Nema sumnje i u godinama koje dolaze, migracije naučnih i tehnoloških talenata ka najrazvijenijim zemljama će naročito biti intenzivirane. Otuda je potrebno zaustaviti gubitak velikog intelektualnog potencijala stvaranjem uslova za realizaciju profesionalnih ciljeva u sopstvenoj zemlji. Ako želimo da postanemo član EU, onda u narednom periodu treba da uspostavimo efikasniju bilateralnu saradnju sa zemljama EU i drugim razvijenim zemljama, naučnim i specijalizovanim ustanovama u svetu na naučno-tehničkom, kulturnom i drugom planu, a radi obezbeđivanja odgovarajuće specijalizacije, stručnog usavršavanja mladih iz Srbije uz obezbeđivanje njihovog povratka i radnog angažovanja u zemlji. Razume se, ciljevi razvoja nameću potrebu i da država treba da bude otvorena za zapošljavanje najboljih stručnjaka/talenata iz inostranstva bilo da su pripadnici naučne dijaspore ili ne. Od profilisanih i vrsnih stručnjaka iz inostranstva, upravo se očekuje da pored znanja, u zemlju donesu preduzetnički duh kontakte i inicijativu.

Za Srbiju je neophodno ulaganje u srednje obrazovanje i visoko obrazovanje. Srbija se nalazi u grupi zemalja koje se po bruto društvenom porizvodu nalaze na nivou srednje razvijenih zemalja u procesu vlasničkih i strukturnih promena. Nivo tehnološkog razvoja Srbije je takav da omogućava kopiranje tehnologija. Kopiranje tehnologije podrazumeva umeće korišćenja postojećih tehnologija i umeće izrade proizvoda sa dostignutim nivoom tehnologije tj proizvodna imitacija. Najveći deo tehnologija u Srbiji je došao putem stranih ulaganja kroz privatizaciju. Jedan deo je došao liberalizaciijom trgovine i uvoza savremene računarske i druge opreme. Stvorili su se uslovi za povećanje produktivnosti uz korišćenje raspoložive tehnologije. Dakle, da bi se povećala produktivnost, zahteva se obučenost ljudi. Do obučene radne snage dolazi se ulaganjem u doobuku u kompanijama i kroz školski sistem prilagođen potrebama i praksi.

Unapređenje proizvodnih procesa, razvoj novih tržišta i organizacija, zahteva i nove kvalifikacije. Zato su u narednom periodu potrebna određena prilagođavanja, koja se ogledaju u sledećem: neophodno je izraditi sistem informisanja o potrebama privrede u pogledu kvalifikacije kadrova, i u skladu sa tim, obrazovni profili se moraju prilagoditi potrebama privrede. Potreban je evropski okvir kvalifikacija za srednje stručno obrazovanje do koga se dolazi prihvatanjem raspoloživog evropskog iskustva prilagođenog mogućnostima Srbije. Dalje, u Srbiji je neophodno, kroz proces stvaranja društvenog partnersta između privrede, obrazovnih institrucija i nacionalne službe za zapošljavanje, školovanje prema potrebama privrednog razvoja. Takođe, neophodan je osmišljeni razvoj klastera, koji u svom sastavu obuhvataju i obrazovne institucije, neophodne za razvoj određenog regiona. Naravno, potrebna je i izuzetna pažnja i adekvatna aktivnost državnih organa, privrednih subjekata, naročito privrednih komora, medija, izvršnih i zakonodavnih tela, u cilju podizanja svesti da bez ulaganja u istraživanja, razvoj i inovacije, nema napretka niti povećanja konkurentnosti privrede Srbije.

Kako je već pomenuto, znanje je osnova privrednog razvoja i povećanja konkurentnosti privrede Srbije i zato je ono ugrađeno u Strategiji naučnog i tehnološkog razvoja kao i drugim dokumentima sistemske regulative. $U$ tom smislu, za pohvalu su aktivnosti koje je pokrenulo Minisatrstvo za nauku i tehnološki razvoj, koje se odnose na: pružanje boljih uslova za život i rad mladim talentima i stručnjacima, ulaganje u infrastrukture naučnih institucija, izgradnja tehnoloških parkova i slično. Ali prosto je neshvatljivo da uprkos saznanjima o izuzetnoj važnosti talenata i stručnjaka za napredak Srbije, Akcioni plan povećanja sredstava za istraživanje i razvoj, kako iz budžeta tako i iz privrede, jeste najslabiji deo sprovođenja Strategije naučnog i tehnološkog razvoja. Otuda se nameće potreba za adekvatnom aktivnošću državnih organa, privrednih subjekata, komora, kao i medija, na podizanju svesti da bez adekvatnog upravljanja ljudskim kapitalom nema ni napretka niti povećanja konkurentnosti privrede Srbije. Na kraju se postavlja pitanje: da li smo sposobni da pokrenemo ljudski kapital i promenimo smer ili ćemo kao društvo i stvaralačka kultura nestati tokom XXI veka?

\section{LITERATURA}

Becker, G. (1975). Human Capital. New York: National Bureau of Economic Research. 
Communication from the Commission. (2010). Europe 2020: a strategy for smart, sustainable and inclusive growth. Brussels: European Commission.

Docquier, F., \& Marfouk, A. (2006). International Migration by Educational Attainment. In C. Özden \& M.W. Schiff (Ed.), International Migration, Remittances, and the Brain Drain. Washington, DC: World Bank.

Drucker, P.F. (2008). Management. New York: Collins.

Keely, B. (2010). Ljudski kaptal: kako ono što znate oblikuje vaš život. Beograd: Zavod za udžbenike.

Kozomara, J. (1994). Tehnološka konkurentnost. Beograd : Ekonomski fakultet.

Krugman, R.P. \& Obstfeld, M. (2009). Međunarodna ekonomija: Teorija i politika. Beograd: Data Status.

Mankiw, N.G., \& Taylor, M.P. (2008). Ekonomija. Beograd: Data Status.

Porter, M. E. (2007). Konkurentska prednost: ostvarenje i očuvanje vrhunskih poslovnih rezultata. Novi Sad: ASEE Books.

Stiglic, Dž.E. (2004). Ekonomija javnog sektora. Beograd: Ekonomski fakultet.

Todaro, P.M. \& Smith, S.C. (2006). Ekonomski razvoj. Sarajevo: Šahinpašić.
Vlada Republike Srbije. (2011). Strategija naučnog i tehnološkog razvoja RS za period od 2010 do 2015. godine. Preuzeto 22. Decembra, 2015. sa http://apv-nauka.ns.ac.rs/images/dokumenti/StrategijaNaucnogITehnoloskogRazvoja.pdf

Vlada Republike Srbije. (2012). Strategija razvoja obrazovanja u Srbiji do 2020. godine. Preuzeto 22. Decembra, 2015. sa http://www.kg.ac.rs/doc/strategija_obrazovanja_do_2020. pdf

Weil, D. N. (2005). Economic growth. Boston: Addison-Wesley.

World Economic Forum. (2012). The Global Competitiveness Report 2010-2011. Preuzeto 22. Decembra, 2015. sa http:// www.weforum.org/reports/global-competitiveness-report-2010-2011-0

World Economic Forum. (2012). The Global Competitiveness Report 2014-2015. Preuzeto 22. Decembra, 2015. sa http:// www.weforum.org/reports/global-competitiveness-report-2014-2015

Zjalić, Lj.M. (2011). Razvoj ljudskih resursa u funkciji strukturalnih promena i novih uslova rada : inovativnost - nezaobilazan činilac razvoja. Beograd: Fakultet za menadžment malih i srednjih preduzeća. 